\title{
Keterlambatan Pengiriman Suku Cadang Kapal Sehingga Mengganggu Kegiatan Operasional Kapal di PT. Global Trans Energy Internasional
}

\author{
April Gunawan Malau ${ }^{1}$, Arif Hidayat ${ }^{2}$, Rendra Wijaya Mada ${ }^{3}$ \\ 1, 2,3 Prodi Ketatalaksanaan Angkutan Laut dan Kepelabuhanan \\ Sekolah Tinggi Ilmu Pelayaran, Jakarta \\ Jl. Marunda Makmur No. 1 Cilincing, Jakarta Utara. Jakarta 14150
}

\begin{abstract}
Abstrak
Kegiatan operasional kapal yang lancar merupakan faktor penting bagi perusahaan dalam mendapat keuntungan. Namun belakangan ini kelancaran keberangkatan kapal di PT Global Trans Energy Internasional sering mengalami gangguan. Karena kapal yang dimiliki oleh PT Global Trans Energy Internasional sudah berumur cukup tua, sedangkan suku cadang yang dibutuhkan kapal tidak memadai. Permintaan suku cadang oleh pihak kapal selalu terlambat, sehingga keberangkatan kapal tertunda. Terlambatnya pengadaan suku cadang mengakibatkan kapal harus menunda perjalanan ke kapal besar dan menunggu sampai suku cadang tiba di atas kapal. Selain itu awak kapal sering tidak memperhatikan ketersediaan suku cadang diatas kapal, sehingga pemesanan suku cadang secara mendadak atau dalam keadaan darurat, padahal proses pengadaan suku cadang memakan waktu yang lama, serta ketersediaan suku cadang di perusahaan terbatas dan kurang lengkap. Oleh karena itu, pengadaan suku cadang tidak boleh diabaikan. Tugas-tugas dari pihak pengadaan hendaknya di jalani dengan sebaik-baiknya, mulai dari memilih supplier atau vendor, membuat rancangan kerjasama dengan supplier, menentukan suku cadang yang sesuai, melakukan pembelian serta mengevaluasi kinerja supplier. Bila pengadaan suku cadang kapal dapat dilakukan tepat waktu, maka waktu keberangkatan kapal terlaksana sesuai dengan jadwal yang telah ditetapkan
\end{abstract}

Copyright $\odot$ 2020, Prosiding Seminar Pelayaran dan Riset Terapan

Kata Kunci: Suku Cadang, Keterlambatan, Operasional Kapal, kualitas, air ketel

Permalink/DOI : https://doi.org/10.36101/pcsa.v2i1.132

\section{PENDAHULAN}

Perusahaan pelayaran sebagai industri jasa transportasi laut memiliki peranan yang sangat penting dalam dunia pelayaran di Indonesia. Salah satunya adalah PT Global Trans Energy Internasional merupakan perusahaan swasta yang bergerak dalam bidang pelayaran. PT Global Trans Energy Internasional adalah perusahaan pemilik kapal yang menyediakan jasa transportasi laut, meliputi jasa angkutan muatan barang curah seperti batu bara.

Kapal yang dimiliki adalah Tug Boat dan Tongkang. Dalam mengopersikan kapal-kapal tersebut PT Global Trans Energy Internasional memiliki manajemen kapal yang terorganisir yang terbagi dari beberapa departemen, yaitu Departemen Operasional, Departemen Teknik, dan Departemen Logistik. Fungsi pengelolaan kapal dari berbagai departemen tersebut meliputi pertanggung jawaban atas armada kapal, pengawasan, pemeliharaan, perawatan, persiapan docking, penyediaan suku cadang, pengawakan, asuransi, dan sertifikasi kelaiklautan kapal.
Tugas dari departemen tersebut saling berkesinambungan dengan kegiatan operasional kapal di PT Global Trans Energy Internasional agar operasi pengapalan dapat berjalan lancar sesuai yang di inginkan perusahaan. Kegiatan operasional kapal yang lancar merupakan faktor penting bagi perusahaan dalam mendapat keuntungan. Namun belakangan ini kelancaran keberangkatan kapal di PT Global Trans Energy Internasional sering mengalami gangguan. Karena kapal yang dimiliki oleh PT Global Trans Energy Internasional sudah berumur cukup tua, sedangkan suku cadang yang dibutuhkan kapal tidak memadai. Permintaan suku cadang oleh pihak kapal selalu terlambat, sehingga keberangkatan kapal tertunda.

Terlambatnya pengadaan suku cadang mengakibatkan kapal harus menunda perjalanan ke kapal besar dan menunggu sampai suku cadang tiba di atas kapal. Selain itu awak kapal sering tidak memperhatikan ketersediaan suku cadang diatas kapal, sehingga pemesanan suku cadang secara mendadak atau dalam keadaan darurat, padahal proses pengadaan suku cadang memakan 
waktu yang lama, serta ketersediaan suku cadang di perusahaan terbatas dan kurang lengkap. Di sisi lain pihak perusahaan tidak membuat rencana pengadaan suku cadang kapal berdasarkan Standar Operasional Prosedur (SOP). Oleh karena itu, pengadaan suku cadang tidak boleh diabaikan. Tugas-tugas dari pihak pengadaan hendaknya di jalani dengan sebaik-baiknya, mulai dari memilih supplier atau vendor, membuat rancangan kerjasama dengan supplier, menentukan suku cadang yang sesuai, melakukan pembelian serta mengevaluasi kinerja supplier.

Bila pengadaan suku cadang kapal dapat dilakukan tepat waktu, maka waktu keberangkatan kapal terlaksana sesuai dengan jadwal yang telah ditetapkan. Hal tersebut tidak menutup kemungkinan pula untuk mendapat keuntungan yang lebih besar pada PT Global Trans Energy Internasional.

Dari beberapa masalah yang ditemukan maka peneliti mencoba untuk merinci identifikasi masalah sebagai berikut :

1. Terlambatnya pengiriman suku cadang kapal ke kapal.

2. Belum maksimalnya pelaksanaan Standar Operasional Prosedur (SOP) dalam penanganan suku cadang kapal.

3. Tidak berjalannya komunikasi antara pihakpihak terkait dalam proses pengadaan suku cadang.

4. Pengiriman suku cadang dari kantor pusat ke kantor cabang melalui jasa pengiriman barang memakan waktu lama.

Dalam penyusunan penelitian ini peneliti akan membatasi masalah seputar faktor keterlambatan pengadaan suku cadang kapal keatas kapal :

1. Terlambatnya pengiriman suku cadang kapal ke kapal.

2. Belum maksimalnya pelaksanaan Standar Operasional Prosedur (SOP) dalam penanganan suku cadang.

Berdasarkan pemahaman pada batasan masalah yang dibahas, maka perumusan masalah dalam penelitian ini menyangkut :

1. Mengapa terlambatnya pengiriman suku cadang kapal ke kapal?

2. Apa yang menyebabkan belum maksimalnya pelaksanaan Standar Operasional Prosedur (SOP) penanganan suku cadang kapal?

Tujuan penelitian ini yaitu untuk mengetahui penyebab terjadinya keterlambatan pengiriman suku cadang ke atas kapal sehingga mengganggu jadwal keberangkatan kapal.

\section{METODE}

Metode Pendekatan yang digunakan dalam penelitian ini adalah metode pendekatan deskriptif kualitatif. Dalam memperoleh data peneliti menggunakan teknik pengumpulan data berupa observasi. Observasi adalah pengumpulan data berupa informasi berdasarkan pengamatan langsung oleh peneliti di di PT. Global Trans Energy.

\section{HASIL DAN PEMBAHASAN}

PT. Global Trans Energy Internasional adalah salah satu bagian dari Baramulti Group Company. Baramulti Group merupakan perusahaan pertambangan batubara yang mempunyai konsesi di Sumatra dan Kalimantan dengan 5 bidang usaha, yaitu Coal Mining, Coal Trading, Transport \& Infrastucture, Shipment dan Mining service. Sejak memulai usaha perdagangan batubara pada tahun 1988, Baramulti Group telah memiliki 11 kontrak pertambangan batubara yang terdiri atas 6 kontrak aktif dan 5 kontrak yang sedang dalam masa pengembangan. Baramulti Group juga telah telah membuka bisnis ekspedisi tahun 1993 dengan total 46 unit kapal tunda dan tongkang serta memiliki 8 floating crane sehingga Baramulti Group dapat memberikan layanan terbaik untuk partner dan klien di masa depan.

PT. Global Trans Energy Internasional masuk ke dalam bidang usaha jasa shipment dengan memiliki 10 unit kapal tunda (tugboat) dan 10 unit kapal tongkang (barge). PT. Global Trans Energy International adalah sebuah Perusahaan Nasional yang berdomisili dan berkantor pusat di Graha Baramulti, Jl. Suryopranoto No. 2 Blok A.8 Jakarta Pusat. Perusahaan didirikan pada tahun 2004 dengan Akte Pendirian NO. 7 tanggal 27 September 2004. PT. Global Trans Energy Internasional bergerak dalam bidang pelayaran dan perkapalan spesialis kapal tunda (tugboat) dan kapal tongkang (barge), perusahaan memiliki kantor cabang di Banjarmasin Kalimantan Timur dan Tarakan Kalimantan Utara.

Seluruh kegiatan tersebut dapat terlaksana karena perusahaan di dukung oleh tenaga kerja yang berpengalaman. Seperti di bagian Operasional dan Teknik, di dukung oleh teknisi terlatih dalam maintenance kapal dan di kendalikan oleh para pimpinan yang kompeten. Di bagian Logistik selain memiliki tenaga yang berpengalaman dalam hal pembelian dan pengiriman juga di dukung oleh pemasokpemasok yang terpilih. 
PT. Global Trans Energy Internasional adalah sebuah perusahaan swasta nasional yang bergerak di bidang jasa angkutan laut dan pendukungnya yang selalu mengutamakan kepuasan pelanggan, memberikan keuntungan yang maksimal kepada perusahaan, pemegang saham dan meningkatkan kesejahteraan karyawan, mengutamakan keselamatan kerja(zero accident), ramah lingkungan serta selalu berupaya meningkatkan produktifitas kerja dan sumber dayanya dengan menerapkan system manajemen mutu ISO 9001:2008 secara berkesinambungan dan sesuai peraturan perundang-undangan yang berlaku.

Struktur organisasi PT. Global Trans Energy International di buat dan ditetapkan berdasarkan keputusan Direktur Utama dengan tetap mempertimbangkan kebutuhan organisasi dan tuntutan pelanggan serta kemujuan perusahaan di masa mendatang. Struktur organisasi ditetapkan dengan tujuan untuk memberikan gambaran yang jelas mengenai tugas, tanggung jawab dan wewenang masing-masing personel secara professional sesuai dengan fungsinya.

Adapun tugas dan wewenang dari struktur organisasi yang ada adalah :

a. President Director

1) Bertanggung jawab atas pencapaian dan target perusahaan kepada share holder.

2) Merancang dan memastikan tujuan dan strategi perusahaan untuk jangka panjang dan pendek

3) Bertanggung jawab atas perkembangan perusahaan

b. Operation Director

1) Mengelola dan meningkatkan efektifitas dan efisiensi operasi perusahaan

2) Memangkas habis biaya-biaya operasi yang sama sekali tidak menguntungkan perusahaan

3) Meneliti teknologi baru dan metode alternatif efisiensi

4) Mengawasi tata letak operasional , persediaan dan distribusi barang

5) Membuat atau merencanakan pengembangan operasi dalam jangka pendek maupun panjang

6) Meningkatkan sistem operasional, proses dan kebijakan dalam mendukung visi dan misi perusahaan

c. Commercial and Support Director

1) Merencanakan serta mengembangkan sumber-sumber pendapatan dan

1) pembelanjaan kekayaan perusahaan

2) Bertindak sebagai perwakilan perusahaan dalam hubungannya dengan luar perusahaan
3) Menetapkan strategi-strategi stategis untuk mencapakai visi dan misi perusahaan

4) Mengkoordinasikan dan mengawasi semua kegiatan di perusahaan, mulai bidang administrasi, kepegawaian hingga pengadaan barang.

Secara umum proses bisnis PT. Global Trans Energy Internasional di bedakan menjadi 3 proses yaitu proses bisnis utama, proses bisnis pendukung dan proses kontrol manajemen. Proses bisnis utama merupakan proses inti dari bisnis PT. Global Trans Energy Internasional yang di mulai dari mencari pelanggan/pengguna jasa, menerima penawaran dari pelanggan termasuk melakukan review terhadap penawaran (dalam costing) atau menerima jadwal ketersediaan kapal dari departemen operasional, mempersiapkan dokumen form booking, merealisasi oprational shipment yang diperoleh. Pemerikasaan terhadap perkembangan realisasi operational dan proses assurance dokumen yang secara continue dilaporkan kepada top manajement. Proses penagihan ke klien dilakukan setelah realisasi shipment sesuai kontrak dilaporkan oleh departemen Quality Assurance.

Armada atau kapal PT. Global Trans Energy International. Berikut adalah list Tug Boat dan Tongkang yang dimiliki dan dioperasikan PT. Global Trans Energy Internasional. Armada tersebut dioperasikan untuk rute pelayaran dalam Negeri dan luar Negeri.

Tabel 1. List Armada yang dimiliki PT. Global Trans Energy Internasional

\begin{tabular}{|c|c|c|c|c|c|c|c|}
\hline \multirow[t]{2}{*}{ No } & \multirow{2}{*}{$\begin{array}{l}\text { NAMA } \\
T U G B O A T\end{array}$} & \multirow[t]{2}{*}{$G T$} & \multirow[t]{2}{*}{$\boldsymbol{H P}$} & \multicolumn{2}{|c|}{$\begin{array}{c}\text { KETETAPAN } \\
\text { PEMAKAIAN } \\
\text { BBM/HARI } \\
\end{array}$} & \multicolumn{2}{|c|}{$\begin{array}{c}\text { MIN. SPEED } \\
\text { (RATA-RATA) }\end{array}$} \\
\hline & & & & Empty & $\begin{array}{c}\text { Full } \\
\text { Loaded }\end{array}$ & Empty & $\begin{array}{c}\text { Full } \\
\text { Loaded }\end{array}$ \\
\hline 1 & $\begin{array}{l}\text { ALPHA } \\
\text { OMEGA }\end{array}$ & 242 & $\begin{array}{l}2400 \\
\text { HP }\end{array}$ & $\begin{array}{l}3285 \\
\mathrm{~L}\end{array}$ & $3686 \mathrm{~L}$ & $\begin{array}{l}5.5 \\
\text { KNOT }\end{array}$ & $\begin{array}{l}4.0 \\
\text { KNOT }\end{array}$ \\
\hline 2 & ALVIN & 220 & $\begin{array}{l}2400 \\
\text { HP }\end{array}$ & $\begin{array}{l}3285 \\
\mathrm{~L}\end{array}$ & $3686 \mathrm{~L}$ & $\begin{array}{l}5.5 \\
\text { KNOT }\end{array}$ & $\begin{array}{l}4.0 \\
\text { KNOT }\end{array}$ \\
\hline 3 & DANIEL & 220 & $\begin{array}{l}2400 \\
\text { HP }\end{array}$ & $\begin{array}{l}3285 \\
\mathrm{~L}\end{array}$ & $3686 \mathrm{~L}$ & $\begin{array}{l}5.5 \\
\text { KNOT }\end{array}$ & $\begin{array}{l}4.0 \\
\text { KNOT }\end{array}$ \\
\hline 4 & ERIC & 229 & $\begin{array}{l}2400 \\
\text { HP }\end{array}$ & $\begin{array}{l}3285 \\
\mathrm{~L}\end{array}$ & $3686 \mathrm{~L}$ & $\begin{array}{l}5.5 \\
\text { KNOT }\end{array}$ & $\begin{array}{l}4.0 \\
\text { KNOT }\end{array}$ \\
\hline 5 & FRED & 219 & $\begin{array}{l}2400 \\
\text { HP }\end{array}$ & $\begin{array}{l}3285 \\
\mathrm{~L}\end{array}$ & $3686 \mathrm{~L}$ & $\begin{array}{l}5.5 \\
\text { KNOT }\end{array}$ & $\begin{array}{l}4.0 \\
\text { KNOT }\end{array}$ \\
\hline 6 & GANDA & 245 & $\begin{array}{l}2400 \\
\text { HP }\end{array}$ & $\begin{array}{l}3285 \\
\mathrm{~L}\end{array}$ & $3686 \mathrm{~L}$ & $\begin{array}{l}5.5 \\
\text { KNOT }\end{array}$ & $\begin{array}{l}4.0 \\
\text { KNOT }\end{array}$ \\
\hline 7 & HENRY & 245 & $\begin{array}{l}2400 \\
\text { HP }\end{array}$ & $\begin{array}{l}3285 \\
\mathrm{~L}\end{array}$ & $3686 \mathrm{~L}$ & $\begin{array}{l}5.5 \\
\text { KNOT }\end{array}$ & $\begin{array}{l}4.0 \\
\text { KNOT }\end{array}$ \\
\hline 8 & IVAN & 251 & $\begin{array}{l}2060 \\
\text { HP }\end{array}$ & $\begin{array}{l}2787 \\
\mathrm{~L}\end{array}$ & $3125 \mathrm{~L}$ & $\begin{array}{l}5.5 \\
\text { KNOT }\end{array}$ & $\begin{array}{l}4.0 \\
\text { KNOT }\end{array}$ \\
\hline 9 & JOHAN & 160 & $\begin{array}{l}1600 \\
\mathrm{HP}\end{array}$ & $\begin{array}{l}2323 \\
\mathrm{~L}\end{array}$ & $2533 \mathrm{~L}$ & $\begin{array}{l}5.0 \\
\text { KNOT }\end{array}$ & $\begin{array}{l}3.5 \\
\text { KNOT }\end{array}$ \\
\hline 10 & KEVIN & 162 & $\begin{array}{l}1600 \\
\text { HP }\end{array}$ & $\begin{array}{l}2323 \\
\mathrm{~L}\end{array}$ & $2533 \mathrm{~L}$ & $\begin{array}{l}5.0 \\
\text { KNOT }\end{array}$ & $\begin{array}{l}3.5 \\
\text { KNOT }\end{array}$ \\
\hline
\end{tabular}




\begin{tabular}{|c|c|l|l|}
\hline No & NAMA BARGE & $\boldsymbol{G T}$ & $\boldsymbol{N} \boldsymbol{T}$ \\
\hline 1 & BAL 5862 & 2318 & 696 \\
\hline 2 & CHRISTY & 3467 & 1032 \\
\hline 3 & DEWI & 3088 & 924 \\
\hline 4 & ERICKA & 3088 & 927 \\
\hline 5 & GLORIA & 3388 & 1017 \\
\hline 6 & HELEN & 3370 & 1011 \\
\hline 7 & LINA & 3345 & 1004 \\
\hline 8 & MERRY & 3345 & 1004 \\
\hline 9 & NANIA & 3373 & 1012 \\
\hline 10 & OLIVIA & 3385 & 1015 \\
\hline
\end{tabular}

Dalam proses pengadaan suku cadang kapal di PT. Global Trans Energy Internasional memiliki tahapan-tahapan yang harus dipenuhi dan disetujui, yang merupakan tugas dan fungsi dari Departemen Logistik dalam pengelolaan kapal di perusahaan. Departemen Logistik akan memproses pengadaan barang dan suku cadang kapal untuk kebutuhan kapal maupun kebutuhan dikantor sesuai SOP yang berlaku di perusahaan. Permintaan hingga pembelian akan suku cadang tersebut memiliki prosedur yang harus dijalani oleh pihak kapal dan pihak perusahaan.

Suku cadang kapal merupakan hal yang perlu diperhatikan oleh pemilik kapal dan dalam pengadaanya harus tepat waktu atau tidak mengalami keterlambatan, karena bila terjadi keterlambatan dalam pengadaan suku cadang kapal dapat mempengaruhi dalam pengoperasian kapal tersebut maka perusahaan harus memiliki program-program yang tepat agar dalam pengoperasian kapal tidak mengalami gangguan yang dapat merugikan perusahaan.

Barang kebutuhan kapal terdiri dari suku cadang, ship store, repair, peralatan dan perlengkapan kantor. Suku cadang kapal merupakan hal yang sangat penting karena jalannya mesin kapal bergantung pada suku cadang yang tersedia diatas kapal akibatnya proses pengapalan mengalami keterlambatan sampai ketempat tujuan.

Adanya keterlambatan pengadaan suku cadang kapal yang mengganggu kegiatan operasional kapal. Hal tersebut dikarenakan oleh beberapa faktor antara lain terlambatnya pengiriman suku cadang kapal ke kapal, belum maksimalnya pelaksanaan SOP dalam penanganan suku cadang kapal.

Data perusahaan monitoring Material Request, Purchase Request, dan Purchase Order yang disajikan dalam penelitian ini milik PT. Global Trans Energy Internasional sebagai berikut
Tabel 2. Monitoring Purchase Request dan

Purchase Order di PT. Global Trans Energy Internasional

\begin{tabular}{|c|c|c|c|c|c|c|}
\hline $\begin{array}{c}\text { NAMA } \\
\text { BARANG }\end{array}$ & $\begin{array}{l}\text { T } \\
\text { G } \\
\text { L } \\
\text { P } \\
\text { R }\end{array}$ & $\begin{array}{c}\text { NOMOR } \\
\text { PR }\end{array}$ & $\begin{array}{l}\text { T } \\
\mathbf{G} \\
\mathbf{L} \\
\mathbf{P} \\
\mathbf{O}\end{array}$ & $\begin{array}{c}\text { NOMOR } \\
\text { PO }\end{array}$ & VENDOR & $\begin{array}{c}\text { LO } \\
\text { KAS } \\
\text { I }\end{array}$ \\
\hline $\begin{array}{l}\text { Tapped assy } \\
\text { fuel M/E }\end{array}$ & \multirow{3}{*}{$\begin{array}{c}03 \\
- \\
\mathrm{Ja} \\
\mathrm{n}- \\
18\end{array}$} & \multirow{3}{*}{$\begin{array}{c}\text { 001/PR/A } \\
\text { O/I/18 }\end{array}$} & \multirow{3}{*}{$\begin{array}{c}09 \\
- \\
\mathrm{Ja} \\
\mathrm{n}- \\
18\end{array}$} & \multirow{3}{*}{$\begin{array}{c}\text { GTI- } \\
01 / 2018 / 00 \\
45\end{array}$} & SARANG & \multirow{2}{*}{$\begin{array}{c}\text { JAK } \\
\text { ART } \\
\text { A }\end{array}$} \\
\hline $\begin{array}{l}\text { Gasket } 12, \\
\text { round M/E }\end{array}$ & & & & & DIESEL & \\
\hline $\begin{array}{l}\text { Blower } \\
\text { portable }\end{array}$ & & & & & $\begin{array}{c}\text { BAJA } \\
\text { TEKNIK }\end{array}$ & $\begin{array}{c}\text { TAR } \\
\text { AKA } \\
\mathrm{N}\end{array}$ \\
\hline Oli Filter ME & \multirow{3}{*}{$\begin{array}{c}06 \\
- \\
\mathrm{Ju} \\
\mathrm{n}- \\
18\end{array}$} & \multirow{3}{*}{$\begin{array}{c}\text { 015/PR/M } \\
\text { ICHAEL/ } \\
\text { VI/18 }\end{array}$} & $\begin{array}{c}06 \\
- \\
\text { Ju } \\
\text { n- } \\
18 \\
\end{array}$ & $\begin{array}{c}\text { GTI- } \\
06 / 2018 / 08 \\
58\end{array}$ & $\begin{array}{l}\text { RIVINDI } \\
\text { ARTHA } \\
\text { MANDIRI }\end{array}$ & \multirow[t]{2}{*}{$\begin{array}{c}\text { JAK } \\
\text { ART } \\
\text { A }\end{array}$} \\
\hline $\begin{array}{l}\text { Water Pump } \\
\text { Assy AE }\end{array}$ & & & $\begin{array}{c}17 \\
-\end{array}$ & $\begin{array}{c}\text { GTI- } \\
07 / 2018 / 10 \\
68\end{array}$ & $\begin{array}{c}\text { SAMUDR } \\
\text { A MITRA } \\
\text { BERSAMA }\end{array}$ & \\
\hline Accu & & & 18 & $\begin{array}{c}\text { GTI- } \\
07 / 2018 / 10 \\
53 \\
\end{array}$ & $\begin{array}{l}\text { SUBUR } \\
\text { JAYA }\end{array}$ & $\begin{array}{c}\text { TAR } \\
\text { AKA } \\
\mathrm{N} \\
\end{array}$ \\
\hline
\end{tabular}

Sumber: PT. Global Trans Energy Internasional 2018

Tabel 3. Monitoring Delivered dan On Board Barang di PT. Global Trans Energy Internasional

\begin{tabular}{|l|c|c|c|c|}
\hline \multicolumn{1}{|c|}{$\begin{array}{c}\text { NAMA } \\
\text { BARANG }\end{array}$} & $\begin{array}{c}\text { TGL } \\
\text { KIRI } \\
\text { M }\end{array}$ & $\begin{array}{c}\text { DELIVERE } \\
\text { D BY }\end{array}$ & $\begin{array}{c}\text { TGL } \\
\text { DITERIM } \\
\text { A }\end{array}$ & $\begin{array}{c}\text { TGL } \\
\text { ONBOAR } \\
\text { D }\end{array}$ \\
\hline $\begin{array}{l}\text { Tapped assy } \\
\text { fuel M/E }\end{array}$ & $\begin{array}{c}07- \\
\text { Feb-18 }\end{array}$ & $\begin{array}{c}\text { PCP } \\
008973251\end{array}$ & 09-Feb-18 & 10-Feb-18 \\
\hline $\begin{array}{l}\text { Gasket 12, } \\
\text { round M/E }\end{array}$ & $\begin{array}{c}17- \\
\text { Jan-18 }\end{array}$ & $\begin{array}{c}\text { PCP } \\
008973274\end{array}$ & 20-Jan-18 & 25-Jan-18 \\
\hline $\begin{array}{l}\text { Blower } \\
\text { portable }\end{array}$ & - & - & 13-Feb-18 & 18-Feb-18 \\
\hline $\begin{array}{l}\text { Oli Filter } \\
\text { ME }\end{array}$ & $\begin{array}{c}03-J u l- \\
18\end{array}$ & $\begin{array}{c}\text { PCP } \\
008973155\end{array}$ & 05-Jul-18 & 11-Jul-18 \\
\hline $\begin{array}{l}\text { Water Pump } \\
\text { Assy AE }\end{array}$ & $\begin{array}{c}23-J u l- \\
18\end{array}$ & $\begin{array}{c}\text { PCP } \\
008973312\end{array}$ & 25-Jul-18 & 29-Jul-18 \\
\hline Accu & - & - & 18-Jul-18 & 29-Jul-18 \\
\hline
\end{tabular}

Sumber: PT. Global Trans Energy Internasional 2018

Berdasarkan monitoring yang dilakukan pihak perusahaan, keterlambatan pengadaan suku cadang kapal yang terjadi dapat dilihat. Daftar suku cadang kapal yang mengalami keterlambatan pada bulan Januari 2018 sampai bulan Juni 2018: Tabel 4. Rekapitulasi Keterlambatan Suku Cadang

\begin{tabular}{|l|c|c|c|c|}
\hline Nama barang & Tgl PR & Tgl PO & Tgl diterima & Tgl onboard \\
\hline $\begin{array}{l}\text { Tapped assy } \\
\text { fuel M/E }\end{array}$ & $\begin{array}{c}03 / 01 / 2 \\
018\end{array}$ & $09 / 01 / 2018$ & $09 / 02 / 2018$ & $10 / 02 / 2018$ \\
\hline $\begin{array}{l}\text { Gasket 12, } \\
\text { round M/E }\end{array}$ & $\begin{array}{c}03 / 01 / 2 \\
018\end{array}$ & $09 / 01 / 2018$ & $20 / 01 / 2018$ & $25 / 01 / 2018$ \\
\hline Blower portable & $\begin{array}{c}03 / 01 / 2 \\
018\end{array}$ & $09 / 01 / 2018$ & $13 / 02 / 2018$ & $18 / 02 / 2018$ \\
\hline Oli Filter ME & $\begin{array}{c}06 / 01 / 2 \\
018\end{array}$ & $06 / 01 / 2018$ & $05 / 07 / 2018$ & $11 / 07 / 2018$ \\
\hline $\begin{array}{l}\text { Water Pump } \\
\text { Assy AE }\end{array}$ & $\begin{array}{c}06 / 01 / 2 \\
018\end{array}$ & $17 / 07 / 2018$ & $25 / 07 / 2018$ & $29 / 07 / 2018$ \\
\hline Accu & $06 / 01 / 2$ & $17 / 07 / 2018$ & $18 / 07 / 2018$ & $29 / 07 / 2018$ \\
\hline
\end{tabular}


Proses pengiriman suku cadang kapal ke kapal di PT. Global Trans Energy Internasional menggunakan sistem sentralisasi dan pergudangan sebagai tempat persediaan suku cadang. Kegiatan pengadaan suku cadang kapal dilakukan oleh Departemen Logistik seperti pemesanan, penerimaan, pengiriman, penataan, dan pengemasan suku cadang. Pengiriman suku cadang kapal ke kapal melalui gudang terlebih dahulu. Pelaksanaan dalam penerimaan suku cadang kapal bila ada kedatangan suku cadang kapal yang dikirim oleh pemasok, pihak perusahaan atau staf departemen logistik akan memeriksa suku cadang kapal tersebut dan dokumen-dokumen yang tertera seperti Invoice dan Tanda Terima bila telah sesuai, pihak perusahaan sebagai penerima harus menandatangani tanda terima tersebut.

Selanjutnya penerima melaporkan ke kepala dan staf departemen logistik bila suku cadang kapal yang dipesan telah sampai dan merencanakan proses pengiriman. Pihak perusahaan akan membuat dokumen pengiriman suku cadang kapal seperti Surat Jalan dan Surat Bukti Barang Keluar. Kemudian pihak perusahaan melakukan proses pengemasan suku cadang kapal yang akan dikirim ke kapal di dalam gudang persediaan, suku cadang kapal tersebut siap dikirim setelah pengemasan selesai dan dilampirkan dengan dokumen-dokumen pendukungnya. Pengiriman suku cadang kapal di PT. Global Trans Energy Internasional bekerja sama dengan perusahaan jasa pengiriman. Setelah suku cadang kapal tiba di kantor cabang, maka staf departemen logistik yang berada di kantor cabang akan menangani penerimaan dan mengantar suku cadang kapal tersebut hingga tiba diatas kapal dan terima oleh pihak kapal.

Dalam pelaksanaan pengadaan suku cadang kapal sering mengalami terlambatnya pengiriman, sehingga proses pengadaan suku cadang kapal akan mengganggu kegiatan operasional kapal di perusahaan. Terlambatnya pengiriman suku cadang kapal disebabkan dari beberapa faktor seperti :

a. Kurangnya komunikasi dan koordinasi antara pihak perusahaan dan pihak kapal yang berkaitan dengan kebutuhan suku cadang kapal diatas kapal

b. Waktu tiba suku cadang kapal tertentu yang harus di import dari luar negeri

Oleh karena itu, semua permintaan suku cadang kapal harus di koordinasikan secara jelas oleh pihak yang berkaitan, pihak perusahaan yang menangani proses pengadaan harus menjalin komunikasi dengan baik dan dapat bekerja sama dengan pihak kapal. Kemudian pemesanan suku cadang kapal juga harus memperhatikan waktu pengiriman hingga suku cadang kapal tersebut tiba, apabila suku cadang kapal harus memesan ke luar negeri atau import. Agar proses pengiriman suku cadang kapal yang dibutuhkan diatas kapal tidak mengalami keterlambatan, sehingga tidak mengganggu jadwal keberangkatan kapal yang telah ditentukan.

Pemesanan suku cadang kapal yang dilaksanakan pihak perusahaan biasanya melalui telegram kepada pemasok, pemesanan suku cadang kapal yang diminta harus membuat dan dituliskan pada Material Request yang diseleksi oleh departemen teknika atau nautika terlebih dahulu dan disahkan Direktur Armada, lalu dikembalikan ke departemen logistik. Setelah seleksi, dibuatkan surat pemesanan barang atau Purchase Order dan Purchase Request yang ditandatangani oleh staf departemen logistik dan kepala departemen logistik. Selanjutnya dikirim kepada pemasok dengan tembusan ke kapal, keuangan, dan yang terkait. Setelah menerima Purchase Request, pemasok mengirim suku cadang kapal ke kantor atau gudang persediaan. Setelah suku cadang diperiksa oleh staf di gudang, staf tersebut harus menandatangani Tanda Terima atau delivery notes (DN). DN asli dikembalikan ke pemasok dan copynya disampaikan ke departemen logistik.

Dalam penanganan suku cadang kapal yang akan dipesan kepada pemasok, pihak perusahaan belum mampu menjalankan proses pengadaan secara maksimal, seperti mengulur waktu pemesanan suku cadang kapal sehingga materials request sudah menumpuk. Hal tersebut dikarenakan staf di departemen logistik melakukan tawar-menawar dengan vendor untuk menentukan atau kecocokan harga suku cadang kapal tersebut. Berlangsungnya komunikasi mengenai harga biasanya melalui e-mail atau handphone, sehingga akan memakan waktu proses pemesanan dan dapat mengakibatkan terlambatnya pengadaan suku cadang kapal.

Kinerja seorang karyawan merupakan hal yang bersifat individual, karena setiap karyawan mempunyai tingkat yang berbeda-beda dalam mengerjakan tugas. Tanggung jawab dalam menyelesaikan masalah dan menjalankan tugas, serta tugas yang diinstrusikan oleh atasan dapat dilihat dari kompetensi yang dimiliki oleh karyawan. Tingkat pendidikan yang ada pada karyawan PT. Global Trans Energy Internasional sudah memadai, namun terjadi ketidaksesuaian dengan pekerjaan yang dilakukan sebagai karyawan dengan kompetensinya. Maka beberapa 
karyawan perlu mendalami pekerjaannya dengan melakukan pembelajaran dan pelatihan terlebih dahulu, agar pekerjaan dapat berjalan dengan baik dan tepat waktu sesuai dengan tujuan bersama.

Adapun alternatif pemecahan masalah sebagai berikut:

\section{Terlambatnya Pengiriman Suku Cadang Kapal} Ke Kapal

a. Pihak kapal menyerahkan daftar kebutuhan suku cadang kapal kepada pihak perusahaan

Untuk mengatasi terlambatnya pengiriman suku cadang kapal ke kapal, pihak kapal membuat daftar kebutuhan suku cadang kapal yang dibutuhkan diatas kapal kepada pihak perusahaan. Dengan cara pihak kapal mengecek secara rutin atau terjadwal keadaan kapal, seperti kerusakan mesin kapal atau suku cadang kapal yang dibutuhkan oleh kapal. Kemudian daftar kebutuhan suku cadang kapal tersebut diserahkan kepada pihak perusahaan agar pihak perusahaan dapat merencanakan proses pengadaan suku cadang kapal keatas kapal, sehingga pengadaan suku cadang kapal tidak terjadi keterlambatan dan suku cadang kapal tersedia diatas kapal dengan tepat waktu.

\section{b. Pihak perusahaan meminta daftar kebutuhan suku cadang kapal kepada pihak kapal}

Pihak perusahaan berperan penting dalam ketersediaan pengadaan kebutuhan suku cadang kapal diatas kapal, agar proses pengadaan suku cadang kapal dapat berjalan dengan baik dan lancar tanpa harus mengalami gangguan mulai dari permintaan atau materials request sampai suku cadang kapal tiba diatas kapal. Pihak perusahaan harus dapat menekan pihak kapal agar memberikan daftar-daftar kebutuhan suku cadang kapal, dengan menerimanya daftar kebutuhan suku cadang kapal secara periodik maka pihak perusahaan akan menyusun rencana pengadaan suku cadang kapal sesuai kebutuhan di kapal.

\section{Belum Maksimalnya Pelaksanaan SOP Dalam Penanganan Suku Cadang Kapal \\ a. Pihak perusahaan membuat rencana kebutuhan suku cadang kapal berdasarkan SOP}

Pelaksanaan penanganan suku cadang kapal di perusahaan harus sesuai dengan SOP yang berlaku, karena pemesanan suku cadang kapal memiliki proses dan prosedur sehingga memerlukan waktu. Untuk mengatasi adanya keterlambatan dalam proses pengadaan, pihak perusahaan harus merencanakan penanganan kebutuhan suku cadang kapal secara maksimal dan berdasarkan SOP. Adanya perencanaan sangat berguna untuk menghindari pemesanan secara tiba-tiba agar keterlambatan pengadaan suku cadang kapal tidak terjadi. Untuk mengetahui prosedur pengadaan suku cadang kapal secara garis besar berikut ini prosedur permintaan, pemesanan, penerimaan, dan pembayaran:

\section{1) Permintaan}

Sesuai perencanaan, pihak kapal mengajukan Materials Request atau daftar kebutuhan kapal untuk permintaan suku cadang kapal. MR tersebut ditandatangani oleh pihak kapal, selanjutnya dikirim kepada pihak perusahaan.

2) Pemesanan

Permintaan dari pihak kapal perlu diseleksi oleh pihak terkait, lalu diberikan kepada departemen logistik. Setelah diseleksi, dibuatkan surat pemesanan barang atau Purcahse Request ditandatangani oleh kepala departemen logistik dan disahkan oleh Direktur Armada. Selanjutnya, dikirim kepada pemasok dengan tembusan ke kapal, keuangan, dan pihak terkait. Departemen logistik membuat surat pemesanan langsung atau Purcahse Order kepada pemasok bila persediaan sudah mencapai batas minimum (safety stock) dan memesan suku cadang kapal sesuai daftar kebutuhan suku cadang kapal yang diberikan pihak kapal. Surat-surat pemesanan tersebut harus disahkan oleh Direktur dan kepala departemen.

\section{3) Penerimaan}

Setelah menerima Purchase Order, pemasok mengirim suku cadang kapal ke gudang atau ke kantor cabang. Setelah suku cadang kapal diperiksa oleh pihak perusahaan dan menandatangani Tanda Terima ke pemasok dan salinannya disampaikan kepada departemen logistik. Pemesanan suku cadang kapal memerlukan waktu, maka suku cadang kapal harus diatur agar mengadakan persediaan pengamanan (safety stock) dan mengatur waktu mulai pesan dengan cara yang biasa disebut dengan EQQ (Eqonomic Ordering Quantity)

\section{b. Pihak kapal memberi masukan pada pihak} perusahaan secara berkala mengenai kebutuhan suku cadang kapal

Pihak kapal memberikan informasi mengenai kebutuhan suku cadang kapal yang terjadi dilapangan atau dikapal, seperti jenis atau spesifikasi suku cadang kapal, keadaan yang sebenarnya di kapal, bahkan waktu yang ditetapkan pihak kapal mengenai kapan kapal akan membutuhkan suku cadang tersebut. Proses Pendukung adalah proses yang mendukung berjalannya proses utama, seperti pengadaan barang (logistic), pengendalian sumber daya manusia dan memastikan segi legitasi terhadap shipment yang ada maupun sedang di proses, penyediaan peralatan beserta perbaikan (repair), 
docking dan perawatan (maintenace) sarana lainnya.

Masukan yang diberikan dari pihak kapal akan sangat membantu pihak perusahaan dalam penanganan suku cadang kapal yang akan dikirim ke kapal, karena pihak kapal lah yang mengetahui secara langsung keadaan kapal. Memberikan masukan secara jelas akan mengurangi tugas pihak perusahaan untuk mencari pemasok yang menyediakan suku cadang yang dibutuhkan dan menghindari pengadaan secara mendadak, pihak perusahaan pun juga harus membuat daftar pemasok yang menyediakan suku cadang kapal tertentu.

Kemudian evaluasi pemecahan masalah untuk kasus terlambatnya Pengiriman Suku Cadang Kapal

a. Pihak kapal menyerahkan daftar kebutuhan suku cadang kapal kepada pihak perusahaan

Kelebihan :

1) Menghindari permintaan dan pemesanan mendadak

2) Suku cadang kapal akan tiba ke kapal tepat waktu

3) Dapat memperkirakan waktu pengadaan suku cadang kapal

4) Memproses permintaan kebutuhan suku cadang kapal sesuai dengan SOP

Kekurangan :

1) Menambah pekerjaan pihak perusahaan

2) Pihak perusahaan mengeluarkan biaya yang lebih banyak

3) Pihak perusahaan harus benar-benar menyeleksi permintaan dari pihak kapal

b. Pihak perusahaan meminta daftar kebutuhan suku cadang kapal kepada pihak kapal

Kelebihan :

1) Menghindari permintaan dan pemesanan mendadak

2) Suku cadang kapal akan tiba ke kapal tepat waktu

3) Dapat memperkirakan waktu pengadaan suku cadang kapal

4) Memproses permintaan kebutuhan suku cadang kapal sesuai dengan SOP

Kekurangan :

1) Menambah pekerjaan pihak perusahaan

2) Pihak perusahaan mengeluarkan biaya yang lebih banyak

3) Pihak perusahaan harus benar-benar menyeleksi permintaan dari pihak kapal

Untuk kasus belum maksimalnya pelaksanaan SOP dalam Penanganan Suku Cadang Kapal, yaitu: a. Pihak perusahaan membuat rencana kebutuhan suku cadang kapal berdasarkan SOP

Kelebihan :

1) Melaksanakan proses pengadaan sesuai dengan SOP

2) Menghindari terlambatnya penanganan dalam suku cadang

3) Mencegah pemesanan secara tiba-tiba Kekurangan :

1) Menambah pekerjaan pihak pekerjaan

2) Banyak melibatkan pihak terkait

3) Kemungkinan ada yang tidak setuju dengan rencana yang dibuat

b. Pihak kapal memberi masukan pada pihak perusahaan secara berkala mengenai kebutuhan suku cadang kapal

Kelebihan :

1) Mempercepat proses pengadaan suku cadang kapal ke kapal

2) Pekerjaan pihak perusahaan menjadi lebih efektif dan efesien

3) Memudahkan pemesanan suku cadang kapal kepada pemasok

Kekurangan :

Komunikasi dari pihak kapal ke pihak perusahaan terhambat oleh sinyal yang sering menghilang ketika berlayar

\section{KESIMPULAN}

Adapun kesimpulan yang diperoleh dari hasil penelitian ini yaitu:

1. Terlambatnya pengiriman suku cadang kapal ke kapal disebabkan oleh suku cadang kapal yang tidak tersedia di perusahaan, yang akan berakibat kapal tidak dapat berangkat sesuai jadwal. Pemecahan masalah yang dapat dilaksanakan adalah pihak kapal memberikan daftar kebutuhan suku cadang kapal secara berkala atau pihak perusahaan yang meminta daftar kebutuhan suku cadang kapal dalam merencanakan pembelian suku cadang.

2. Belum maksimalnya pelaksanaan SOP dalam penanganan suku cadang kapal disebabkan karena sumber daya manusia yang belum memadai, sehingga pengadaan suku cadang kapal tidak terencana sesuai SOP. Solusi yang dapat diambil adalah pihak perusahaan membuat rencana kebutuhan suku cadang kapal sesuai SOP. Alasannya, kinerja pihak perusahaan dalam proses pengadaan suku cadang kapal harus diperhatikan agar penanganannya dilaksanakan dengan tepat waktu dan berdasarkan SOP.

Kemudian saran yang peneliti berikan diantaranya 
1. Terlambatnya pengiriman suku cadang kapal ke kapal pemecahan masalahnya pihak kapal sebagai pengganti pemecahan masalahnya.

2. Belum maksimalnya pelaksanaan SOP penanganan suku cadang kapal pemecahan masalahnya adalah pihak perusahaan membuat rencana kebutuhan suku cadang kapal sesuai SOP dan pihak kapal memberi masukan kepada pihak perusahaan secara berkala mengenai pengadaan suku cadang kapal yang dibutuhkan oleh kapal.

\section{DAFTAR PUSTAKA}

[1]. Engkos Kosasih, Hananto Soewedo. 2007. Manajemen Perusahaan Pelayaran. Jakarta: Raja Grafindo Persada

[2]. Dr.Rusdiana,M.M. 2014. Manajemen Operasi. Bandung: Pustaka Setia

[3]. Capt.Suyono. 2007. Shipping. Jakarta: PPM

[4]. Hoesien,MSc., Capt.Daniel M. 2012. Kamus Istilah Pelayaran dan Perkapalan. Jakarta: Citra Harta Prima

[5]. Goenawan Danuasmoro. 2003. Manajemen Perawatan. Jakarta: Bina Citra Samudera

[6]. Saifudin Azwar. 2007. Metode Penelitian. Yogyakarta: Pustaka Pelajar 